\title{
Water use efficiencies of maize cultivars grown under rain-fed conditions
}

\author{
Daniel Kwasi Asare*, Justice Okona Frimpong, Emmanuel Ofori Ayeh, Harry Mensah Amoatey \\ Department of Plant and Soil Sciences, Biotechnology and Nuclear Agriculture Research Institute, Ghana Atomic Energy Commis- \\ sion, Legon-Accra, Ghana; ${ }^{*}$ Corresponding Author: daniel_asare@yahoo.com
}

Received 10 February 2011; revised 10 March 2011; accepted 28 March 2011.

\begin{abstract}
Enhancing water use efficiencies of rain-fed maize is a requirement for sustainable maize production, particularly in areas prone to lowl drought and erratic rainfall patterns. This study was conducted to assess the relationship between total biomass/grain yield and water use efficiencies of three maize cultivars (Golden Crystal, Mamaba and Obatanpa) grown under rain-fed conditions in a coastal savannah agroecological environment of Ghana. Results of the study showed that a unified linear model, WUE $_{T D M}=0.03$ TDM with $R^{2}=0.765$ and $P \leq$ 0.001 , described adequately the relation between water use efficiency and total biomass (dry matter), which is applicable for the three maize cultivars for both the major and minor cropping seasons. A linear model could only, however, describe adequately well the relation between $W U E_{G Y}$ and $G Y$ for the major $\left(W U E_{G Y}=\right.$ 0.001 GY $\left.-0.67 ; R^{2}=0.996 ; P \leq 0.001\right)$ and minor $\left(W U E_{G Y}=0.002 G Y+0.289 ; R^{2}=0.992 ; P \leq 0.001\right)$ cropping seasons for all the maize cultivars. The linear models developed for the maize cultivars, relating $W U E_{G Y}$ to $G Y$, are specific to each of the crop growing seasons, indicating that seasonal rainfall impacts significantly on harvest index of the maize cultivars but differently in each of the crop growing seasons as a results of differences in seasonal rainfall. However, the models could be used to estimate water use efficiencies of each of the three maize cultivars given the appropriate TDM and GY as inputs for the environment under which the study was conducted.
\end{abstract}

Keywords: Water Use Efficiency; Maize Cultivars; Rain-Fed

\section{INTRODUCTION}

Maize (Zea mays L.) is grown over a wide range of climatic conditions, differing in distribution and quantity of seasonal rainfall. Besides, the crop is grown under irrigated and rain-fed conditions. Rain-fed maize production forms about $75 \%$ of agriculture in areas where the crop is the main source of food and income for the people [1].

Though maize thrives best on soils having adequate moisture during the growing season, the crop tolerates dry periods, especially during the first three to four weeks of growth. In areas such as the semi-arid and dry sub-humid environments, including the coastal savannah environment, the amount of rainfall is not only the limiting factor of rain-fed maize production but also the erratic nature of rainfall [2,3]. However, water stress occurring at different crop developmental stages could potentially limit biomass accumulation and consequently reduce grain yield of the maize crop. The extent of reduction in maize productivity depends not only on the severity of the water stress or drought but also on the stage of the crop development [4,5], the crop tolerance to water stress/drought and the efficiency with which the maize crop uses available soil water for growth, biomass accumulation and yield production.

Water use efficiency of rain-fed maize has been studied by several workers including Frimpong et al. [6] and Tijani et al. [7]. These studies are important for identifying maize cultivars that are efficient in the use of limited soil water for biomass and grain yield production. Identified maize cultivars, when adopted by farmers, could assist in enhancing sustainable maize production in areas where rain-fed agriculture is mostly practiced, particularly in areas that experience low and erratic rainfall. Additionally, with the potential impact of climate change on agriculture as a result of reduced and erratic rainfall in some regions, it has become more imperative to breed or select crops that could use effectively and efficiently low and scarce soil water without drastically constraining crop production in areas that 
depend mostly on rain-fed agriculture, and thereby sustaining crop production and alleviating poverty among resource-poor farmers.

The relationships between grain yield and water use by maize have received attention from several workers. These relationships have been found to be either linear (Adamtey et al. [8], Oktem et al. [9], Yazar et al. [10], Istanbulluoglu et al. [11] and Irmark et al. [12]) or curvilinear (Cetin and Bilgel [13] and Yazar et al. [10]). Similarly, Grassini et al. [14] and Abbas et al. [15] observed a linear relationship between water use efficiency and biomass under irrigated conditions. Our study, therefore, evaluates the relationship between water use efficiencies and biomass/grain yields of three maize cultivars grown under rain-fed conditions in a coastal savannah environment of Ghana.

\section{MATERIALS AND METHODS}

Field experiments were conducted during the 2008 year under both the major and minor cropping seasons (Frimpong et al. [6]). Specifically, experiments were established at the research farm of the Biotechnology and Nuclear Agriculture Research Institute of the Ghana Atomic Energy Commission, Kwabenya-Atomic (Ghana). The site lies on latitude $05^{\circ} 40^{\prime} \mathrm{N}$ and longitude $0^{\circ} 13^{\prime} \mathrm{W}$, elevated at $76 \mathrm{~m}$ above sea level. The study area is located in the coastal savannah environment of Ghana and receives an annual rainfall that ranges between $700 \mathrm{~mm}$ and $1000 \mathrm{~mm}$. The soil at the site is the Haatso series, a well-drained savannah ochrosol described as Ferric Acrisol, (FAO/UNESCO, [16]), derived from quartzite schist. Some of the chemical and physical characteristics of some of the soil are presented in Table 1. The $\mu$ METOS $^{\circledR}$, a micro electronic weather station (Pessl Instruments $\mathrm{GmbH}$, Weiz, Austria) located about $50 \mathrm{~m}$ from the experimental plots recorded daily weather variables including precipitation.

Maize cultivars used for the experiments were Golden Crystal, Mamaba and Obatanpa which were bred for high grain yield and improved nutritional status $[17,18]$. The maize cultivar Mamaba is a three-way hybrid quality protein maize [19] while Golden Crystal and Obatanpa are normal open pollinated maize [17]. Of these maize cultivars, Obatanpa has been widely adopted by farmers, covering more than $50 \%$ of maize acreage in Ghana and other parts of West Africa [20,21].

Seeds of the maize cultivars were sown on April 28, 2008 and September 012008 for the major and minor cropping season, respectively. Seeding was done at a distance of $0.4 \mathrm{~m}$ within rows and $0.8 \mathrm{~m}$ between rows. Seedlings were thinned to 2 plants per hill one week after germination to obtain 78,750 plants $^{-1} \mathrm{~h}^{-1}$. A total of $275.0 \mathrm{~kg} \cdot \mathrm{ha}^{-1}$ of 15:15:15 NPK fertilizer was split-applied by broadcasting two weeks and four weeks after germination [17]. Weeds were controlled mechanically by hoeing whenever necessary. A $100 \mathrm{~mL}$ broad spectrum insecticide, Pyrinex 48 EC (O, O-Diethyl 0-3, 5, 6-trichloro-2-pyridylphosphorothionate) in $100 \mathrm{~L}$ of water was split-applied five and seven weeks after crop establishment during the major and minor cropping seasons. The experimental design used was the randomized complete block design in four replicates with the three maize cultivars as treatments. Each sub-plot measured $10.0 \mathrm{~m}$ by $10.0 \mathrm{~m}$.

Access tubes were installed in each of the sub-plots to $120 \mathrm{~cm}$ soil depth before $50 \%$ seed germination. The tubes were installed in between two central rows within each sub-plot to facilitate in situ moisture monitoring at $20 \mathrm{~cm}$ stepwise in a $120 \mathrm{~cm}$ soil profile with the CPN (Campbell Pacific Nuclear) 503DR Hydro (neutron) probe at a two-week interval throughout the entire maize growing seasons.

Eight maize plants were sampled at 28, 42, 56, 70, 84 and 98 days after emergence (DAE) from an area of 1.28 $\mathrm{m}^{2}$ in each sub-plot. Plant samples were separated into leaves, stem, ear, cob, husk and grain components. Subsamples of fresh plant components were oven-dried at $70^{\circ} \mathrm{C}$ until constant weights for total dry matter determination. Additionally, grain yield at crop maturity was taken from a $10.5 \mathrm{~m}^{2}$ area on August 8, 2008 and December 10, 2008 for the major and minor cropping season, respectively. Grain yield was determined at grain moisture content that ranged between $13.0 \%$ and $15.0 \%$.

Actual evapotranspitation (AET) for the maize cultivars was estimated from seed emergence to crop maturity using the water balance model of the root zone [22]:

Table 1. Some of the chemical and physical properties of the soil at the experimental site (Frimpong et al., 2011).

\begin{tabular}{|c|c|c|c|c|c|c|c|c|c|}
\hline Soil Layer (cm) & $\begin{array}{c}\mathrm{pH}\left(\mathrm{H}_{2} \mathrm{O}\right) \\
(1: 2)\end{array}$ & $\begin{array}{c}\text { Org. C } \\
(\%)\end{array}$ & $\begin{array}{c}\text { Total N } \\
\text { (\%) }\end{array}$ & $\begin{array}{c}\text { Avail. P } \\
\left(\mathrm{mg} \cdot \mathrm{kg}^{-1}\right)\end{array}$ & $\begin{array}{c}\mathrm{K} \\
\left(\mathrm{cmol}+\mathrm{kg}^{-1}\right)\end{array}$ & $\begin{array}{l}\text { Sand } \\
(\%)\end{array}$ & $\begin{array}{l}\text { Silt } \\
(\%)\end{array}$ & $\begin{array}{l}\text { Clay } \\
(\%)\end{array}$ & $\begin{array}{c}\text { Bulk density } \\
\left(\mathrm{kg} \cdot \mathrm{m}^{-3}\right)\end{array}$ \\
\hline $0-20$ & 7.33 & 1.06 & 0.36 & 11.07 & 0.41 & 41.4 & 43.2 & 15.4 & 1.34 \\
\hline $20-40$ & 7.39 & 0.50 & 0.34 & 6.79 & 0.30 & 40.4 & 44.7 & 14.9 & 1.22 \\
\hline $40-60$ & 7.83 & 0.50 & 0.31 & 4.28 & 0.25 & 45.3 & 43.8 & 10.9 & 1.41 \\
\hline $60-80$ & 7.99 & 0.39 & 1.26 & 3.89 & 0.19 & 48.0 & 41.1 & 11.1 & 1.33 \\
\hline $80-100$ & 7.79 & 0.36 & 0.42 & 2.40 & 0.21 & 46.3 & 43.0 & 10.7 & 1.47 \\
\hline $100-120$ & 7.85 & 0.23 & 1.13 & 2.10 & 0.22 & 55.8 & 36.4 & 7.8 & 1.38 \\
\hline
\end{tabular}




$$
\Delta S=P+I-R-D-A E T
$$

where $P$ is precipitation (mm), $I$ is irrigation (mm), AET is actual evapotranspiration (mm) $R$ is run-off (mm), $D$ is drainage or capillary rise $(\mathrm{mm})$ and $\Delta S$ is the change in stored soil moisture in the root zone (mm).

Irrigation $(I)$ was set to zero as the experiments were conducted under rain-fed conditions. Run-off was also set to zero because the slope of the land is less than $1 \%$. Drainage or capillary rise $(D)$ below the root zone (100 cm below the soil surface) was estimated based on the Darcy's water flux model integrated over the measuring time interval:

$$
D=-\left[K(\theta) \frac{\Delta H}{\Delta z}\right] \Delta t
$$

where $K(\theta)$ is the hydraulic conductivity $\left(\mathrm{mm} \cdot \mathrm{d}^{-1}\right.$ ) corresponding to the soil moisture content $(\theta), \Delta H$ is the change in hydraulic head ( $\mathrm{mm}$ ) which is made up of the change in matric potential $\left(\Psi_{\mathrm{m}}\right)$ and change in gravimetric potential $\left(\Psi_{\mathrm{g}}\right), \Delta z(\mathrm{~mm})$ is the difference between the two soil depths at which $\Psi_{\mathrm{m}}$ and $\Psi_{\mathrm{g}}$ were estimated for $\Delta H$ computation and $\Delta t$ (d) is the measuring time interval. The hydraulic conductivity and matric potential were estimated using the pedo-transfer functions given by Campbell [23] with soil particle fractions as inputs.

The water use efficiency $\left(\mathrm{kg} \cdot \mathrm{ha}^{-1} \cdot \mathrm{mm}^{-1}\right)$ of the maize cultivars was estimated in terms of total above ground biomass (WUE $\left.E_{T D M}\right)$ :

$$
W U E_{T D M}=\frac{C T D M}{C A E T}
$$

and in terms of grain yield (WUE $\left.E_{G Y}\right)$ :

$$
W U E_{G Y}=\frac{G Y}{C A E T}
$$

where CTDM and $G Y$ are cumulative total above ground biomass $\left(\mathrm{kg} \cdot \mathrm{ha}^{-1}\right)$ and grain yield $\left(\mathrm{kg} \cdot \mathrm{ha}^{-1}\right)$, respectively, and $C A E T$ is the cumulative actual evapotranspiration (mm).

Water use efficiency was regressed against total biomass and grain yield for each of the maize cultivars for the major and minor cropping seasons. Additionally, biomass and water use efficiency data were pooled together and then regressed to assess the possibility of establishing a unified regression equation relating water use efficiency and total biomass or grain yield application for all the rain-fed conditions (major and minor cropping seasons).

\section{RESULTS AND DISCUSSIONS}

Weather conditions were different during the major and minor cropping seasons. Generally, the mean maximum and minimum temperatures were $30.5^{\circ} \mathrm{C}$ and $23.5^{\circ} \mathrm{C}$, respectively, mean relative humidity was $81.4 \%$, mean solar radiation was $212.1 \mathrm{~W} \cdot \mathrm{m}^{-2}$ and seasonal rainfall was $502.4 \mathrm{~mm}$ during the major cropping season. For the minor cropping season, however, the mean maximum and minimum air temperatures were $31.9^{\circ} \mathrm{C}$ and $23.6^{\circ} \mathrm{C}$, respectively, mean relative humidity was $78.2 \%$, the mean solar radiation was $229.7 \mathrm{~W} \cdot \mathrm{m}^{-2}$ while the seasonal rainfall was $290.7 \mathrm{~mm}$ [6].

Soil water use efficiency is an important crop index used to assess how soil water is used efficiently for total biomass and grain yield production [24]. Generally, the maize cultivars had similar WUE that increased from seed emergence and peaked on $84 \mathrm{DAE}$ at about 18.0 $\mathrm{kg} \cdot \mathrm{ha}^{-1} \cdot \mathrm{mm}^{-1}$ before declining to about $6.0 \mathrm{~kg} \cdot \mathrm{ha}^{-1} \cdot \mathrm{mm}^{-1}$ on 98 DAE during the major cropping season. A similar trend was observed for the minor cropping season, however, the maize cultivar Obatanpa had the highest WUE for biomass production of about $32.0 \mathrm{~kg} \cdot \mathrm{ha}^{-1} \cdot \mathrm{mm}^{-1}$ on 56 DAE and all the maize cultivars had similar $W U E_{T D M}$ values of about $28.0 \mathrm{~kg} \cdot \mathrm{ha}^{-1} \cdot \mathrm{mm}^{-1}$ on $70 \mathrm{DAE}$ before declining to about $10.0 \mathrm{~kg} \mathrm{ha}^{-1} \cdot \mathrm{mm}^{-1}$ on $98 \mathrm{DAE}$ during the minor cropping season. Generally, the seasonal $W U E_{T D M}$ for the maize cultivars for the major cropping season were comparable to the value of $8.0 \mathrm{~kg} \cdot \mathrm{ha}^{-1} \cdot \mathrm{mm}^{-1}$ reported by Mox et al. [25] for rain-fed maize in eastern Zambia while $W U E_{T D M}$ for the maize cultivars during the minor cropping season was higher than values reported by Mox et al. [25] but 1 fell below the range 16.5-21.5 $\mathrm{kg} \cdot \mathrm{ha}^{-1} \cdot \mathrm{mm}^{-1}$ reported by Dagdelin et al. [26]. The comparatively higher season $W U E_{T D M}$ for the maize cultivars during the minor season compared to values for the major season was due to higher biomass accumulated at relatively lower seasonal evapotranspiration [6].

For $W U E_{G Y}$, the maize cultivar Mamaba had significantly the highest value of about $13.0 \mathrm{~kg} \cdot \mathrm{ha}^{-1} \cdot \mathrm{mm}^{-1}(P \leq$ 0.05) during the major cropping season compared to values for the other two maize cultivars. However, $W U E_{G Y}$ for the maize cultivars during the minor cropping season were statistically similar and ranged from 19.0 $\mathrm{kg} \cdot \mathrm{ha}^{-1} \cdot \mathrm{mm}^{-1}$ for Obatanpa, $15.4 \mathrm{~kg} \cdot \mathrm{ha}^{-1} \cdot \mathrm{mm}^{-1}$ for Mamaba to $14.6 \mathrm{~kg} \cdot \mathrm{ha}^{-1} \cdot \mathrm{mm}^{-1}$ for Golden Crystal. Similar $W U E_{G Y}$ values ranging from $11.0 \mathrm{~kg} \cdot \mathrm{ha}^{-1} \cdot \mathrm{mm}^{-1}$ to 18.0 $\mathrm{kg} \cdot \mathrm{ha}^{-1} \cdot \mathrm{mm}^{-1}, 9.3 \mathrm{~kg} \cdot \mathrm{ha}^{-1} \cdot \mathrm{mm}^{-1}$ to $13.8 \mathrm{~kg} \cdot \mathrm{ha}^{-1} \cdot \mathrm{mm}^{-1}$ and $11.4 \mathrm{~kg} \cdot \mathrm{ha}^{-1} \cdot \mathrm{mm}^{-1}$ to $14.4 \mathrm{~kg} \cdot \mathrm{ha}^{-1} \cdot \mathrm{mm}^{-1}$ have been reported by Tijani et al. [7], El-Tantawy et al. [27] and Meena et al. [28], respectively, for maize grown under rain-fed conditions.

Linearly regressing $W U E_{T D M}$ against $T D M$ for each of the maize cultivars resulted in a good linear model with $\mathrm{R}^{2}$ values that ranged between 0.890 and 0.928 for the major cropping season (Table 2). Similar results were obtained for the minor cropping season except that $\mathrm{R}^{2}$ values ranged between 0.756 and 0.864 (Table 2). 
Table 2. Relationship between water use efficiency $\left(W U E_{T D M}\right)$ and total dry biomass (TDM) for three maize cultivars during the major and minor cropping seasons and for the combined seasons.

\begin{tabular}{ccccc}
\hline $\begin{array}{c}\text { Cropping } \\
\text { Season (s) }\end{array}$ & $\begin{array}{c}\text { Maize } \\
\text { Cultivar (s) }\end{array}$ & Regression model & $\begin{array}{c}\text { Correlation } \\
\text { Coefficient }\left(\mathrm{R}^{2}\right)\end{array}$ & $P$-value \\
\hline Major & Golden Crystal & $W U E_{T D M}=0.002 \times \mathrm{TDM}+1.26$ & 0.890 & $\leq 0.001^{* *}$ \\
Major & Mamaba & $W U E_{T D M}=0.002 \times \mathrm{TDM}+1.02$ & 0.918 & $\leq 0.001^{* *}$ \\
Major & Obatanpa & $W U E_{T D M}=0.002 \times \mathrm{TDM}+1.09$ & 0.928 & $\leq 0.001^{* *}$ \\
Minor & Golden Crystal & $W U E_{T D M}=0.003 \times \mathrm{TDM}+3.19$ & 0.864 & $\leq 0.001^{* *}$ \\
Minor & Mamaba & $W U E_{T D M}=0.002 \times \mathrm{TDM}+2.85$ & 0.845 & $\leq 0.001^{* *}$ \\
Minor & Obatanpa & $W U E_{T D M}=0.003 \times \mathrm{TDM}+5.86$ & 0.756 & $\leq 0.002^{* *}$ \\
Major + Minor & Golden Crystal & $W U E_{T D M}=0.003 \times \mathrm{TDM}+1.70$ & 0.822 & $\leq 0.001^{* *}$ \\
Major + Minor & Mamaba & $W U E_{T D M}=0.003 \times \mathrm{TDM}+1.22$ & 0.792 & $\leq 0.001^{* *}$ \\
Major + Minor & Obatanpa & $W U E_{T D M}=0.003 \times \mathrm{TDM}+2.71$ & 0.697 & $\leq 0.001^{* *}$ \\
& & & & $\leq 0.001^{* *}$ \\
\hline
\end{tabular}

${ }^{* *}$ Highly significant

The regression coefficient (slope of the linear regression model) values of $0.003 \mathrm{~mm}^{-1}$ for Obatanpa, 0.002 $\mathrm{mm}^{-1}$ for Mamaba and $0.003 \mathrm{~mm}^{-1}$ for Golden Crystal (Table 2) suggest that the maize cultivars generally behaved similarly during the major and minor cropping seasons in terms of efficient use of soil water for biomass production. Consequently, $W U E_{T D M}$ and TDM data for both cropping seasons and for each maize cultivar were combined for a single linear regression model. The same regression coefficient was obtained for each maize cultivar but significantly different $\mathrm{R}^{2}$ value of 0.697 for Obatanpa, 0.792 for Mamaba and 0.822 for Golden Crystal (Table 2). Additionally, linear regression analysis of all $W U E_{T D M}$ and TDM for all the maize cultivars resulted in a unified linear regression model, $W U E_{T D M}=$ 0.003 TDM +1.89 with $\mathrm{R}^{2}$ value of 0.765 (Table 2). Thus, a single linear model adequately describes the relationship between biomass accumulation of the three maize cultivars and their associated $W U E_{T D M}$ for the combined major and minor cropping seasons.

Linear regression of $W U E_{G Y}$ against grain yield $(G Y)$ for all the maize cultivars resulted in good linear models with $\mathrm{R}^{2}$ of 0.996 and 0.992 for the major (Figure 1(a)) and minor (Figure 1(b)) cropping seasons, respectively, indicating grain yield of these maize cultivars strongly related to $W U E_{G Y}$. This strong agreement between $W U E_{G Y}$ and $G Y$ for the maize cultivars is in agreement with results obtained by Adamtey et al. [8] for maize grown in pots under greenhouse conditions. However, the linear model between $W U E_{G Y}$ and $G Y$ for all the maize cultivars combined for the major and minor cropping seasons resulted in a linear model, $W U E_{G Y}=0.002 G Y+$ 0.48 with $R^{2}$ value of 0.548 . Thus, the three maize cultivars partitioned biomass for grain production differently for each of the cropping seasons (major and minor) in view of the fact that seasonal rainfall was $502.4 \mathrm{~mm}$ for the major cropping season and $290.7 \mathrm{~mm}$ for the minor cropping season [6]. This, therefore, suggests that season rainfall has an impact on biomass partitioning for grain yield in maize and consequently has effects on $W U E_{G Y}$.

\section{CONCLUSIONS}

A linear model adequately described the relationship between $W U E_{T D M}$ and TDM for the maize cultivars Mamaba, Golden Crystal and Obatanpa for each of the major and minor cropping seasons. Additionally, a unified linear regression model adequately described the relationship between $W U E_{T D M}$ and TDM applicable for both the major and minor cropping seasons. Thus, the linear regression models could be used to estimate the efficiency with which the three maize cultivars used soil moisture efficiently for total biomass production under rain-fed conditions in the area of study using TDM as inputs. Besides, the models developed could be useful for quick assessment of $W U E_{T D M}$ for the maize cultivars using easily measured TDM. Aside this, the measurement of WUE of crops is generally a tedious task which involves actual evapotranspiration measurement, Therefore, the developed $W U E_{G Y}-G Y$ linear models would go a long way to assist in determining $W U E_{G Y}$ of the maize 


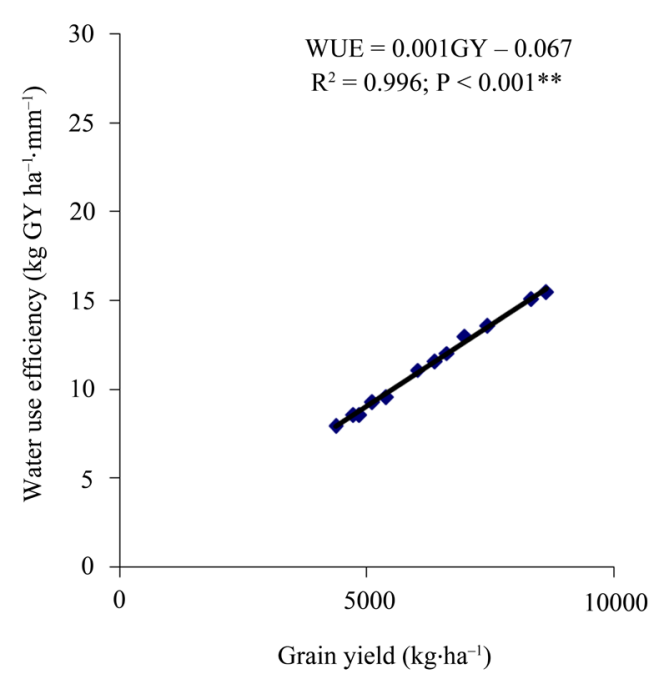

(a)

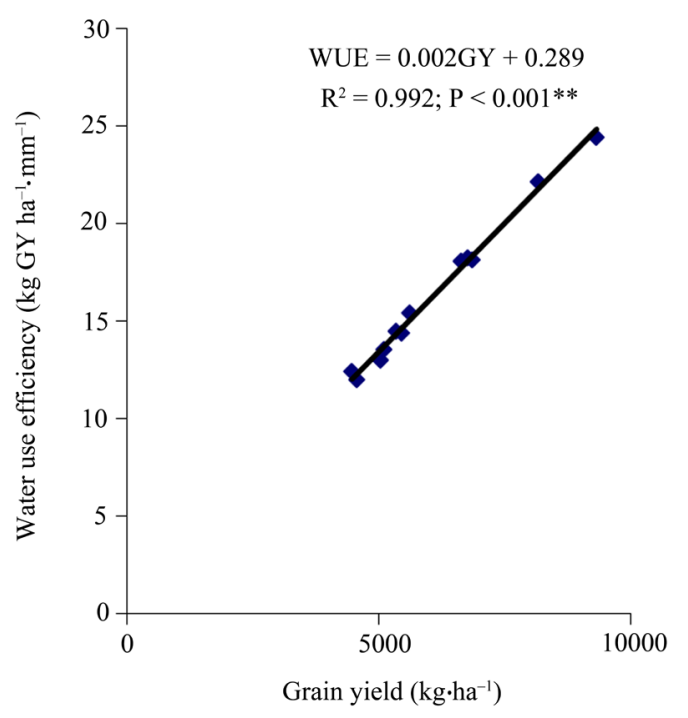

(b)

Figure 1. Linear regression between water use efficiency and grain yields of three maize cultivars during the (a) major and (b) minor cropping seasons.

cultivars and, consequently, the soil water used for producing the measured grain yield without estimating actual evapotranspiratin. However, linear models developed between $W U E_{G Y}$ and $G Y$ were good for the maize cultivars for each of the major and minor cropping seasons, as seasonal rainfall had influence on biomass partitioning for grain yield production of the maize cultivars. Thus, a unified linear model for the combined major and minor cropping seasons applicable for all the maize cultivars resulted in a fairly good linear model. Consequently, linear models developed between $W U E_{G Y}$ and $G Y$ appeared season specific for each of the cropping seasons as biomass partitioning is sensitive to the amount of seasonal rainfall.

\section{REFERENCES}

[1] Rockström, J., Karlberg, L., Wani, S.P., Barron, J., Hatibu, N., Owesis, T., Bruggeman, A., Farahani, J. and Qiang, Z. (2010) Managing water in rain-fed agriculture - The need for a paradigm shift. Agricultural Water Management, 97, 543-550.

[2] Hatibu, N., Young, M.D.B., Gowing, J.W., Mahoo, H.F. and Mzirai, O.B. (2003) Developing improved dry land cropping systems for maize in semi-arid Tanzania. Part 1: Experimental evidence of the benefits of rainwater harvesting. Journal of Experimental Agriculture, 39, 279-292. doi:10.1017/S0014479703001285

[3] Cakir, R. (2004) Effect of water stress at different development stages on vegetative and reproductive growth of corn. Field Crops Research, 89, 1-16. doi:10.1016/j.fcr.2004.01.005

[4] Wani, S.P., Pathak, P., Sreedevi, T.K., Singh, H.P. and Singh, P. (2003) Efficient management of rainwater for increased crop productivity and groundwater recharge in Asia. In: Kijne, J.W., Barker, R. and Molden, D., Eds., Water Productivity in Agriculture: Limits and Opportunity for Improvement. CABI Publishing and International Water Management Institute, Wallingford, 56.

[5] Zaidi, P.H., Rafique, S., Rai, P.K. and Singh, N.N. (2003) Response of maize (Zea mays L.) genotypes to excess soil water stress: Morpho-physiological efforts and basis of tolerance. European Journal of Agronomy, 19, 383399. doi:10.1016/S1161-0301(02)00090-4

[6] Frimpong, J.O., Amoatey, H.M., Ayeh, E.O. and Asare, D. K. (2011) Productivity and soil water use by rainfed maize genotypes in a coastal savannah environment. International Agrophysics, 25, 123-129.

[7] Tijani, F.O., Oyedele, D.J. and Aina, P.O. (2008) Soil moisture storage and water-use efficiency of maize planted in succession to different fallow treatments. International Agrophysics, 22, 81-87.

[8] Adamtey, N., Cofie, O., Ofosu-Budu, K.G., Ofosu-Anim, J., Laryea, K.B. and Forester, D. (2010) Effect of $\mathrm{N}$-enriched co-compost on transpiration efficiency and water-use efficiency of maize (zea mays L.) under controlled irrigation. Agricultural Water Management, 97, 995-1005. doi:10.1016/j.agwat.2010.02.004

[9] Oktem, A., Simsek, M. and Okem, A. G. (2003) Deficit irrigation effects on sweet corn with drip irrigation system in a semi-arid region. I. Water-yield relationship. Agricultural Water Management, 61, 63-74. doi:10.1016/S0378-3774(02)00161-0

[10] Yazar, A., Sezen, S.M. and Gencel, B. (2002) Drip irrigation of corn in the southeast Anatolia Project (GAP) area in Turkey. Irrigation Drainage Journal, 51, 293-300. doi:10.1002/ird.63

[11] Istanbulloglu, A., Kocaman, I. and Konuku, F. (2002) Water production relationship of maize under Tekirday conditions in Turkey. Pakistan Journal of Biological Science, 5, 287-291. doi:10.3923/pjbs.2002.287.291

[12] Imark, S., Haman, D.Z. and Basting, R. (2000) Determination of crop water stress index for irrigation timing and yield estimation of corn. Agronomy Journal, 92,12211227. doi:10.2134/agronj2000.9261221x

[13] Cetin, O. and Bilgel, L. (2002) Effect of different irriga- 
tion methods on shedding and yield of cotton. Agricultural Water Management, 54, 1-15.

doi:10.1016/S0378-3774(01)00138-X

[14] Grassini, P., Yang, H. and Cassman, K. G. (2009) Limits to maize productivity in the western corn-belts: A simulation analysis for fully irrigated and rainfed condition. Agricultural and Forest Meteorology, 149, 1254-1265. doi:10.1016/j.agrformet.2009.02.012

[15] Abbas, G., Hussain, A., Ahmed, A. and Wajid, A.S. (2005) Water use efficiency of maize as affected by irrigation schedules and nitrogen rates. Journal of Agriculture Society Science, 4, 339-342.

[16] FAO/UNESCO (1994) Soil map of the world, revised legend. World Resources Report 60, FAO, Rome, 146.

[17] Afakpui, G.K.S., Abdulai, M.S., Berchie, J.N., Ennim, S. and Sallah, P.Y.K. (2005) Maize production guide, Food Crops Development Project, MoFA, CSIR and SARI,15.

[18] Osei, S.A. , Atuahene, C. C., Okai, D. B., Donkoh, A. and Tuah, A. K. (1997) The nutritive value of quality protein maize in the diets of broiler chickens. Ghana Journal of Agricultural Science, 31, 1-5.

[19] Asiedu, E.A., Sallah, P.Y.K., Twumasi-Afriyie, S., Obeng,-Antwi, K., Ahenkora, K. and Adusei-Akowah, P. (2001) Agronomic and post harvest characterization of the three quality protein maize hybrids develoed in Ghana. Ghana Journal of Agricultural Science, 34, 57-62.

[20] Dankyi, A.A., Sallah, P.Y.K., Adu-Appiah, A. and Gyamera-Antwi, A. (2005) Determination of the adoption of quality protein maize, obatanpa, in Southern Ghana-Logistic regression analysis. Paper presented at the 5th West and Central Africa Regional Maize Workshop, IITA-Cotonou, Benin Republic, 2-7 May 2005, 6-13.

[21] Morris, M.L., Tripp, R. and Dankyi, A.A. (1999) Adoption and impacts of improved maize production technology: A case study of the Ghana Grains development project. Economics Program Paper 99-01, Mexico City, 33-41.

[22] Hartman, R.H. (1998) Soil water balance. International Centre for Theoretical Physics, College of Soil Physics, Trieste, 14-30 April 1997, 73-86.

[23] Campbell, G.S. (1985) Soil Physics with Basic: Transport models for soils-plant systems. Development in Soil Science, 14, Elsevier Science Publishers B.V., Amsterdam Netherlands, 150.

[24] Hunsaker, D.J., Kimball, B.A., Printer, P.J. Jr., La Mante, R.L. and Wall, G.W. (1996). Carbon dioxide enrichment and irrigation effect effects on wheat evaporation and water use efficiency. Transactions of ASAE, 39, 1345-1355.

[25] Mox, X., Liu, S., Lin, Z., Xu, Y., Xiang, Y. and Mcvicar, T.R. (2005) Prediction of yield, water consumption and water use efficiency with a SVAT - Crop growth model using remotely sensed data on the North China Plain. Ecological Modelling Journal, 183, 301-322. doi:10.1016/j.ecolmodel.2004.07.032

[26] Dagdelin, N., Yilmaz, E., Sezgin, F. and Gurbuz, T. (2006) Water-yield relation and water use efficiency of cotton (Gossypium hirsutum L.) and second crop corn (Zea mays L.) in western Turkey. Agricultural Water Management, 82, 63-85. doi:10.1016/j.agwat.2005.05.006

[27] El-Tantawy, M.M., Ouda, A.S. and Khalil, A.F. (2007) Irrigation scheduling for maize grown under Middle Egypt conditions. Research Journal of Agriculture and Biological Sciences, 3, 456-462.

[28] Meena, R.P., Meena, R.P. and Bhimavat, B.S. (2009) Moisture use functions and yield of rain-fed maize as influenced by indigenous technologies. Asian Agric History, 2, 155-158. 